SCHWEITZER Gábor

tudományos főmunkatárs MTA TK JTI

habilitált egyetemi docens NKE ÁKK
DOI: 10.15170/DIKE.2017.01.01.04

\title{
„Újabb időkben sok magyar utazik a mívelt külföldön” Politikai-társadalmi útirajzok a 19. század első feléből
}

\section{„Recently Many Hungarians Are Traveling to the Civilized Abroad” Political and Social Travelogues from the First Half of the 19th Century}

This paper examines how Hungarian travelers presented and characterized the legal system, constitutional life, political, educational and social institutions of Western European countries and the United States in their travel diaries and travelogues in the first half of the 19th century. The authors of these works such as Bertalan Szemere, Sándor Farkas Bölöni, Miklós Wesselényi and others, were among the supporters of the constitutional, political and social reforms in Hungary during the reform era. The basic goal and the prior aim of these travel diaries was to make comparisons between the Hungarian constitutional, political and social institutions with the similar institutions of western states and societies.

Keywords: travel diary, travelogue, 19th century, reform era, constitution, constitutional institutions, political life, educational institutions, West Europe, United States

1. „Szemere Bertalannak a sajtót e napokban elhagyott utazását már olvastam. Meleg philantropi szellemtöl van áthatva, a leggondosb figyelemmel jegyzé föl mind åt, mit külföldrül honunkba átültetni üdvös volna. Vannak benne csekély fontosságú dolgok is, és sok mi csak a' sžerzó egyéniségére tartozónak látszik, de a' bájos elöadás ezeket is igen érdekesség teszi, s' menti az is, hogy napló alakban van a' mü irva, miben a' gondolatoknak, s' érzelmeknek is helye van."1 - ezeket a sorokat Szücs Miklós, egy alig húsz esztendős fiatalember jegyezte a naplójába 1840. szeptember 6-án. A politikai, társadalmi és kulturális élet kiemelkedő eseményeit gondosan megörökítő jogvégzett naplóíró figyelmét azonban nemcsak Szemere Bertalan nyugateurópai útleírása keltette fel, hiszen a Bölöni Farkas Sándor észak-amerikai útinaplóját is többször átlapozta.

Bölöni Farkas Sándor 1834-ben Kolozsvárott megjelenő Utazás Észak-Amerikában című könyve, valamint Sžemere Bertalan „Utazás külföldön” címû 1840-ben Budapesten (!) kiadott munkája a legismertebb reformkori politikai-társadalmi útirajzok, útleírások, útilevelek és útinaplók közé tartozik. A korszak sajtója és könyvkiadása fontosnak is tartotta ezeknek a múveknek a közzétételét. Aki azonban nem kívánt vesződni a cenzúrával, külföldön próbálkozott nyomdát,

\footnotetext{
${ }^{1}$ SZÜCS, Napló 90. 1840. szeptember 6-i bejegyzés.
} 
illetve kiadót keresni kötete számára. Ezt a megoldást választotta Irinyi József, aki 1846-ban Halléban tette közzé „Német-francia és angolországi úti jegyzetek” című könyvét.

A nyugati világot bemutató útirajzok szerzőinek többsége - miként Szalay László, Szemere Bertalan, Pulsæky Ferenc, Tóth Lörinc, Gorove István, Irinyi József, Erdélyi János - a politikai és társadalmi reformokat szorgalmazó, de legalábbis támogató politikusok, tudósok, szellemi és közéleti személyiségek közül került ki. ${ }^{2}$ Az útleírások közzétételét a hétköznapi látnivalók bemutatása mellett az is motiválhatta, hogy a nyugat-európai alkotmányos, jogi, politikai és társadalmi intézmények megismertetésével a hazai politikai és társadalmi reformok számára is felvillantsanak megoldási lehetőségeket. Az útirajzok szerzői alkalmanként össze is hasonlították a hazai állapotokat a külföldön látott és tapasztalt megoldásokkal. Az útleírások, útilevelek és útinaplók ebben a tekintetben a hazai jogi komparasztika első hajtásait is jelentették, miközben magától értetődően nem tudományos célzattal és módszerrel készült munkákról van szó. ${ }^{3} \mathrm{Az}$ összehasonlítás mellett óhatatlanul felmerül a recepció, illetve az adaptáció kérdése is. Mennyiben szükséges, illetve lehetséges a nyugat-európai államokban látott intézmények átvétele, illetve alkalmazása a hazai reformok előmozdítása érdekében? Erre a kérdésre nem adható egyféle válasz. Az útleírások szerzői közül Irinyi József óva intett a mechanikus átvételtől, hiszen miközben a nyugati államok kétségkívül megérdemlik figyelmünket, a külföldi példa az ész világító fénye mellett „csak másodrendü dolog legyen a bizonyító okok sorában." S Szemere Bertalan viszont az átvétel szükségessége mellett érvelt: „Mint küsqködünk mi azzal, ami itten rég megfejteték, mint tapogatjuk félénken, mi itten rég világos. (...) Utazás sok idöt s eröt megkimél, sok kürdéstöl s kételytül megment, és nekünk, kike a pályán az. utósók közt vagyunk, nem találni, csak eltanulni, nem keresni, csak válas:tani, nem teremteni, csak másolni kell." 5 Szalay László sem látott különösebb kivetnivalót abban, ha Magyarország „utánozza” az angol és francia „alkotmányos státusélet” megoldásait, amennyiben együtt kíván múködni az „európai népcsaláddal'. ${ }^{6}$

Nem minden útirajz íródott kifejezetten politikai-társadalmi célzattal. Az 1830-as évek közepén Svájcban és Itáliában utazgató Wesselényi Polixéna figyelmét mindenekelôtt a mûvészeti és természeti látnivalók, valamint a társas élet terei kötötték le, bár találó politikai és társadalmi jellegű észrevételeket is tett. Genfi tartózkodása csalódást keltettek az útleírás szerzője számára a politikaifilozófiai eszmék és a társadalmi valóság közt tapasztalt ellentmondások. „Odahagyni a szabadság, polgári egyenlöség respublikának nevez̧ett földpontocskáját - fájt. Mily hatalma van reánk nézve egy gyerekekorunkban tisztelni megtanult névnek! Ámbár polgári egyenlöséget és szabad nemzet magas erényeit - amint tapasz̧talás nélküli képzeletim lehetségesnek. festették vala - nem találtam. Respublikai képzetimmel éppen ellenkezó" volt ezen rideg kasztokra osztott emberi hangyaboly; mert Geneva polgárai oly szoros, áthághatatlan, különrekesztó kasz̨tokra vannak elosżtva, mint hajdanában Egyiptom lakóji. (...) Respublikeai egyenlöséggel álmadozók! Ne

\footnotetext{
${ }^{2} \mathrm{~A}$ reformkori nyugat-európai utazások politikai és társadalmi jelentőségéhez lásd: FENYŐ, A polgárosodás eszmevilága 603-612., továbbá KAJTÁR, A 19. századi modern magyar állam- és jogrendszer 41., valamint KECSKEMÉTI, Magyar liberalizmus 117-118.

3 A hazai összehasonlító jogtudomány kialakulásához újabban lásd HALÁsz, Wenzel Gusztáv és a magyar jogi komparatisztika kezdetei 152-162.

${ }^{4}$ IRINYI, Német-francia- és angolországi úti jegyzetek 11.

${ }^{5}$ SZEMERE, Utazás külföldön 9.

${ }^{6}$ SZALAY, Eredetiség 's utánzás 207.
} 
válasszátok. Genevát ideáltok típusának. Ennek emberi egyenlöséget birdetö filozófusa képzelt respublikeajához. sclavok tartoztak??

A természettudós Nagy Károly az 1830-as évek elején jutott el Amerikai Egyesült Államokba. A hazai sajtóban megjelenő útilevelei politikai-társadalmi kérdéseket alig-alig érintettek. A kivételek egyikeként viszont mély együttérzéssel számolt be az őshonos indián lakossággal szembeni embertelen bánásmódról. „A szegény honföldiekröl - az. Indusokeól - kik. e 'státusban még itt's amott egy két nemzetségben nyomorún léteznek, majd személyesen fogok neked bolmit elbeszélni. Szívem szorong 's vérzik keblemben, ba 'boldogtalan emberfaj eszembe jut; borzadok, ha meggondolom, mint nyomják ki a 'fejér emberek e' faj maradékait lassanként az, anyaföldröl (...). Atok a' civilisatióra, ha ezen áron nyeri terjedését?’s

Nem mindenki publikálta a külföldi utazási élményeket rögzítő naplókat. A hosszú időt külföldön töltő Széchenyi István, vagy az éppenséggel Széchenyi Istvánnal Nyugat-Európában és Angliában utazgató Wesselényi Mikelós nem jelentették meg az utazások során készített naplókat, feljegyzéseket. Múveikben természetesen felhasználták a külföldi tartózkodás során szerzett ismereteket és tapasztalatokat. Eötvös József ugyan azt tervezte, hogy nyugat-európai utazásairól szóló feljegyzéseit közzéteszi, de végül a svájci utazásokról készült kéziratot nem adta ki, franciaországi tapasztalatait pedig a „Karthauzi” címú regénybe építette be. Saalay László az Athenaeum hasábjain jelentetett meg néhány közleményt az útinaplókból, ám tudományos műveiben, miként „A büntető eljárásról, különös tekintettel az esküttszékekre” címen közzétett munkájában bőségesen kamatoztatta a nyugat-európai tanulmányúton szerzett ismereteket.

A politikai útirajzok, illetve útinaplók szerzői közül többen rendkívül tudatosan készültek a nagy utazásra. Wesselényi Miklós - nem sokkal nyugat-európai utazásai előtt - a következő sorokat jegyezte fel naplójába: „Gyermekekoromtól fogva már élt bennem a vágy utazások által magamat javitani, erösbiteni, idegen, müvelt népek ismeretével önmagamat erkölcsileg és ész̧belileg tovább fejlesżteni s a természet változatos szépségeit, a dolgozó emberek merész alkotásait szemlélni és élvezni." A felkészülés jegyében Wesselényi Miklós még angol nyelvleckéket is vett. Szalay László az Athenaeum címú folyóiratban megjelenő úti naplójában hivatkozott arra, hogy ifjúkori legforróbb vágyai közé tartozott „egy nap láthatni a külföldet."10 Bölöni Farkas Sándor pedig a következő sorokat írta az úti készülődés idején Gedő József nevü barátjának: „Össz̨el szándékszom - úgymond - innen mintegy másfél vagy két esztendôkre elmenni. Az ég meghallgatta kérésem, s talán elérem ąt, mi életemnek, egyik. fövebb obajtása volt, vagyonomnak egy része feláldozásába kerül ugyan, de ennél szebb kivánságomra soba sem költök. Én most mint egy deák, szüntelen tanulok: geographiai, statistikai és constitutiói ismereteket kell elóre szereznem."11

Széchenyi István és Wesselényi Miklós sokáig tervezték egy közös amerikai út lehetőségét. Naplóikban erről többször tettek említést. Lelkesedésüket leginkább az válthatta ki, hogy az Amerikai Egyesült Államokat, miként egyik feljegyzésében Wesselényi Miklós fogalmazott, a

\footnotetext{
7 WESSELÉNYI , Olaszhoni és schweizi utazás. http://mek.oszk.hu/01000/01017/01017.htm

${ }^{8}$ NAGY, Utazási töredékek Éjszak-Amerikából 410. Nagy Károly múködéshez lásd BARTHA, Egy reformkori tudós 27-32 valamint ZÁvODSZKY, Az Amerika-motívum 122 ff.

${ }^{9}$ SZÉCHENYI - WESSELÉNYI, Feleselő naplók 73, 1821. október 29-bejegyzés.

${ }^{10}$ SZALAY, Úti naplómból 370.

${ }^{11}$ Bölöni Farkas Sándor levelét Gedó Józsefhez. (1829. március 30.) idézi: JAKAB, Bölöni Farkas Sándor és kora 291.
} 
szabadság azon dicső hazájának tekintették, amelyet még nem fertőzött meg a szolgaság levegője. ${ }^{12}$ Az amerikai út azonban elmaradt, hiszen az angol partoknál végül nem jutottak tovább.

2. De mi kelthette fel Szǘs Miklós figyelmét a politikai-társadalmi útirajzok olvasásakor? Szemere Bertalan a következő témákat ajánlotta olvasói figyelmébe kötete bevezetőjében: „... Németföldön különösen a népiskolákat, Franciaországban a nyilvános életet, Nagy-Britanniában a fogházakat s népjellemet (...) választám az̧on fénypontul, mi körül egyéb tárgyak csoportozatai összegyülnek."13 Bölöni Farkas Sándor pedig elsősorban amiatt ragadott tollat, mert „a a amerikai polgári és társasági életben sik oly pontot találtam tökéletre kiffejtve, és sok oly tudnivalót, mik még nálunk, legalább magyarul, ismeretlenek."14

Szemere Bertalan tehát Szászország és Poroszország kapcsán mindenekelőtt a népoktatási rendszer működését emelte ki: „Míg Nyugat népei papiralkotványokért dulakodnak, a csendes Németország polgári rendet nevel, mely mind a francia, mind az angol középosztálynál müveltebb lévén, erösb, tömöttebb s állandóbb leend. E nagy munkán dolgozik minden, hatalmával a kormány, részuétével a nép, szellemi erejével a tudós." 15 A szász és porosz népoktatási rendszer bemutatását követóen jó szívvel javasolta a hazai törvényhozás számára, hogy ezen minták nyomán szabályozza, illetve szervezze meg a népoktatási rendszert. Miközben Szemere Bertalan Franciaországot a szabadság, Olaszországot a múvészetek, Angliát az emberész hazájának tartotta, addig Poroszországot a népnevelés hazájaként mindhárom előbb említett állam fölé helyezte. ${ }^{16}$

Pulsæky Ferenc hasonlóan vélekedett Poroszországról az 1836-os úti jegyzetekben: Poroszország ugyan nem rendelkezik alkotmánnyal, „de van két erösebb institutiója, melly a’ népbe mélyen behat, 's a' jólétet biztositja": a népiskola, amely a „legalsóbb rendekig" terjeszti a tudományt, valamint a három évig tartó Landwehr, amely a nemzet számára férfiasabb és nemesebb tartást biztosított. ${ }^{17}$

Irinyi József viszont úgy látta, hogy a porosz népnevelés mögül hiányzik az alkotmányos szabadság, a politikai élet, amelyek nélkül mesebeszéd a nép múveltségével előállni. A nép műveltségének legjobb eszközének az alkotmányos élet megteremtését tekintette. ${ }^{18}$ Irinyinek amúgy az volt a véleménye, hogy az államjogi szempontból felszabdalt, központ - ahogy nevezte: alap nélküli német térségben mûködő államok nem élnek valóságos államéletet: „Németország valósággal nem is egyéb, mint üvegházi növény." 19

Wesselényi Miklós érdeklődését mindazonáltal felkeltették a bajor és a württembergi alkotmányos monarchia alapintézményei. Müncheni tartózkodása idején a naplóíró nagyon készült arra, hogy részt vegyen a törvényhozó testület egyik ülésén, de erre a látogatásra végül időhiány

\footnotetext{
12 SZÉCHENYI - WESSELÉNYI, Feleselő naplók 75. 1821. november 2-i bejegyzés: „Széchenyivel reggel 91/2 órakor Czenkre kiindultunk. Mely különbség a minapi bejövetelünk s mostani kimenetelünk közt. Akkor mind csak utunkról, Amerikáról, elindulásunkról beszéltünk, lelkesitve lehellet reánk a szabadság azon dicső hazájának a szolgaság által még meg nem fertőztetett levegője szép képzetinkbe. Most mindazokról egy szót sem. Mindazon kitételek helyett, melyeket Széchenyi egy órában tizszer is mondott: „Du wirst schon in England sehen” "Auf unserer Reise nach Amerika” most egy-egy fagyos „Solltest Du jemals nach England kommen” „Sollten wir je zusammen eine Reise machen” vet ki számomra."

13 SZEMERE, Utazás külföldön 9.

14 BÖLÖNI, Napnyugati utazás 281.

15 SZEMERE, Utazás külföldön 27. 1836. október 19-i bejegyzés.

16 SZEMERE, Utazás külföldön 67. 1836. november 2-i bejegyzés.

17 PULSZKY, Úti vázlatok 46.

${ }^{18}$ IRINYI, Német-francia- és angolországi úti jegyzetek 33 ff.

${ }^{19}$ IRINYI, Német-francia- és angolországi úti jegyzetek 26.
} 
miatt nem kerülhetett sor. „A rendek épen össze vannak gyülve. Nagyon sajnálom, hogy egy ülést sem láthatok, mert ma még nem lészen és holnap annyira kell sietnünk, hogy nem maradhatunk. 2 órával tovább itt, e nekünk, magyaroknak oly érdekes dolgot végig hallgatni. Hogy ezen gÿ̈lekezet céljánake és méltóságának megfelel-e vagy nem, bogy igaz, vagy igaztalan úton jár-e - egyformán érdekes és tanulságos lenne tudni. Annál is inkább kivántam volna az. egybegyült rendeket közelebbröl látni és hallani, mert itt egészẹn különös módon tárgyalják mükëdésüket: nevetnek rajtuk. A bibának vagy a megitélö tömegben, vagy a rendek gyülekezetében kell lennie, de mindkét esetben óriási és a jövöre nézve nagyon káros. Úgy hallom, hogy igen szabadon beszélnek, közbe-kǫ̈̈be súlyosan támadják a felelös minisztereket. Különben eddig még egy kiváló szónokuk sincs, de hogy is volna ez - sör és kifött gombócok mellett - lehetséges?" - fogalmazott az útinapló számára. ${ }^{20}$ Württemberg ugyanakkor a bécsi kongresszus óta, Wesselényi Miklós értékelése szerint, a kor szelleméhez képest igen liberális alkotmánnyal rendelkezett. „A miniszterium felelös. A tanácskozások megkezdésekor maga a király proponálja az újonnan behozandó törvényeket s mig e terveket le nem tárgyalták, a rendek nem tehetnek önálló propositiokat. Ily módon a király csak elegendö munkával kell ellássa a rendeket, és bižtos lehet, hogy oppositiora nem kerülhet sor. A törvényeket a király szentesiti; ha a király megtagadja valamely törvény szentesitését, három év mulva üjra tárgyaltatik e törvény. A rendek minden harmadik évben gyülnek össze. Szónoki tehetségek itt ép oly kevéssé vannak, mint Bajorországba, de a nyelv (sváb tájszólás) igazán nem szónoklásra való s egy ily sváb Demosthenes bizonyára mulatságos lehet."21

A bajor királyág alkotmányos intézményeirôl viszont Tóth Lörincnek igen kritikus véleménye volt. Az alkotmány elismerte ugyan a szabadságjogokat, de garanciákkal már nem bástyázta körül azokat. „Bajororşág alkotmányos orşág, alkotmánya 1818-ki csinálmány. Hasonlit a' többi német alkotmányokhoz, mellyekbe sok ép elv van lefektetve, életerö nélkül, mert hiányzanak azon garantiák, mellyek biz̧⿻sítják az életet. (...) A' bajor alkotmányban is, mint a' többi német alkotmányok' nagyobb részében ki van mondva a' lelkisméret', a' vélemény', a' szólás' szabadsága, de olly törvényes megszoritásokekal a' lehetö visszaélések. ellen, mellyek határozatlan magyarázatúak 's a' magyarázat' kulcsa a' hatalom' kezében lévén, az önkénynek, tárt kaput nyitnak, 's a' szerencsétlen megelózón rendsžer' szabadságellenes szabályai szerint úgy korlátozva, 's akkint készîtve el, hogy a' fényes theoriákból alig képes a' kijätszott élet valamit megmarkolni. Ki van mondva a' státus polgárok' egyenlösége fegyver- adó- 's egyébb terherviselésben, hivatalképességben, s' a' törvény elött, de különös rendkivüli esetekben kivételek 's kedvezmények vannak fentartva, mellyek a' szabályt magát azonnal megsemmisitik, mihelyt a' hatalomnak ügy teszik..'22 Pulszky Ferencet a szászországi alkotmányos monarchia se hozta lázba: „Szász-országban, a’ reformatio' honában, most egy szülkmellü aljas szellem uralkodik a' népnél, melly constitutionalismus által palástoltatik, de mindekekoráig bizonyos, hogy két kamararendszerö̈k csak annyiban volt hasznos, mennyiben a' nép látja, milly nehéz. országot közumegelégedésre kormányozni." ${ }_{23} \mathrm{Az}$ úti feljegyzésekben viszont Bölöni Farkas Sándor elismeréssel írt a bajor alkotmányos monarchiáról, de némi túlzással azt állította, hogy a bajor uralkodó „nemes magamegtagadással' mondott le az abszolút uralomról, és az arisztokrácia, valamint a papság által elnyomott nép számára szabad konstitúciót adott. ${ }^{24}$

\footnotetext{
${ }^{20}$ SZÉCHENYI - WESSELÉNYI, Feleselő naplók 128-129. 1822. március 5-i bejegyzés.

${ }^{21}$ SZÉCHENYI - WESSELÉNYI, Feleselő naplók 131. 1822. március 7-i bejegyzés.

22 TótH, Úti tárcza 82-83.

23 PULSZKY, Úti vázlatok 45.

${ }^{24}$ BÖLÖNI, Napnyugati utazás 103. 1830. december 5-i bejegyzés.
} 
De hadd folytassák útjukat Frankhon felé! Szemere Bertalan érdeklődését Franciaországban leginkább a „nyilvános élet” színterei keltették fel. Részletesen ismertette a választási rendszer intézményeit, valamint a kétkamarás törvényhozó testület működését. A komparatisztika jegyében

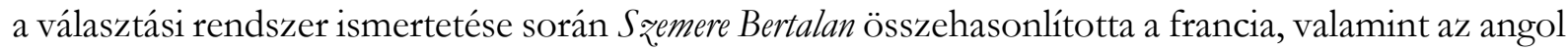
„követkamara” és a magyar alsótábla társadalmi, foglalkozási összetételét. „Nálunk a követkart teszi: táblabiró, ügyvéd, tisztviseló. De mi ez más, mint három névvel nevezett egy személy? Ehhez, adok két-három tudóst. Már most hol van a kereskedési-s iparérdeknek értelmes képviselöje? A városi követek sz̨inte csak tisz̨viselök, s ha másképpen volna is, hiszen nincs szavok. (...) Külföldön ez. mind másképpen áll. A követek közt van ügyvéd, biró, birtokos, kereskedó, tudós, bivatalnok a kormány minden ágaibul, katona, gyárnok, és mi legtöbb exminiszter. Hogy jobban meggyözödjél, barátom, vizsgáld meg, a magyar, francia, angol követház mi elemekböl van szerkesz̨tve. A francia ez évi kamarában van: miniszter 5, miniszteri bivatalban dolgozó 8, tábornagy 1, vezérrangú tisz̨t 19, ęredesen aluli 20, alhajóvezér 1, a béke, törvényszéke, királyi s cassatio-tábla birái közül 74, miniszterkövet idegen udvaroknál 2, statustanácsnok s ezen tanácshoz tartozó 18, egyetemektöl 3, királyi mérnök 4, finánci tárnok 1, hadi tárnok 8, stb., sqóval királyi szolgálatbeli 164, ę̧en kivül: ügyész 46, orvos 8, kereskedó, pénquáltó és gyámok. 39, vashámorok birtokosa 8, jegyző 4, és föld- báz töpénz̧birtokos 178, sqóval nem királyi bivatalbeli 283, összesen $=447$. Az angol ez idei albázban van: lord 59, hajóvezér 3, vezér 14, squárazi s tengeri alsóbb tiszt earedestöl a hadnagyig 142, lord-helynök 7, alhelynök 42, lovag, baronet s ily rangú 153, ügyész. 61, pénquáltó 40, kelet-indiai birtokos 33, nyugoti 17, kormánybivatalnok. 52, sinecurista 114. A magyar követtáblán 1832-ben volt: alispán 42, táblabiró 36, alsóbb bivatalbeli 27, a városok részéról részint biró, részint tanácsbeli 74, sqóval a követtábla állt 179 törvénytudóbul és 44 teológbul. Könnyü átlátni, barátom, hogy a föladatokat jobban az a törvényhozás fejtheti meg, mely magában több ágbeli férfiakat egyesit." 25 A következtetés egyértelmû: az a törvényhozó testület képes az érdemibb munkavégzésre, amelynek tagjai szélesebb spektrumban reprezentálják a foglalkozási ágakat. Anglia kapcsán az útleírás szerzője az alsóházi képviselő és az alsótáblai követ státusza közti különbségre is rámutatott. „Itt a követ az egész ország képviselóje, nem a válasz̨tott megyéé vagy városé, mi okbul itt utasitások nincsenek, mert az ország képviselöjének. azokat csak nemzet adhatna (mi törvény lenne), nem pedig egy tartomány. Azok tehát, kik egyiránt az egész nép képviselöi, kikeet utasitás nem köt s mégis egyértenek, inkább és természetesen fölvehetik a barát nevezetet, mert itt a politikai hit és sqó, éppúgy, mint a squv érzése, pusz̧tán a követé, mint egyedés nem mint utasitott képviselóé. (...) A 658 tag tehát az alház̧̧an inkább ugyanannyi egyed, semmint követ; nálunk inkább ugyanannyi këvet, semmint egyed. Azok tanácskoznak s végeznek, meggyözódésökön kivül senkire nem ügyelve, mint a nemzet föltétlen megbizottai, küldvék az ország külön részébül; követeink pedig jobb kezeiket az utasitásra, balaikat keblökre teszik, mindkettöre kell hallgatniok." 26 A francia illetve angol törvényhozás megválasztására, összetételére és múködésére vonatkozó tudósítások eléggé egyértelműen utalnak arra, hogy az útinapló szerzője szerint felettébb időszerű lenne a hazai törvényhozás szervezeti és múködési reformja.

Az igazságszolgáltatási rendszer bemutatása során Szemere Bertalan részletesen szólt az esküdtszékről, már csak amiatt is, mert Magyarországon még a közügyeket vezérlők között sem

\footnotetext{
${ }^{25}$ SZEMERE, Utazás külföldön 186. 1837. február 14-i bejegyzés.

${ }^{26}$ SZEMERE, Utazás külföldön 268-269. 1837. június 7-i bejegyzés.
} 
sokan ismerték akkoriban ezt az intézményt. ${ }^{27}$ Az esküdtszék jelentőségét legfőképp abban látta, hogy ez az intézmény teremtette meg az ártatlanságnak a legerősebb és legszilárdabb biztosítékát. A nyilvános élet színterei közül természetesen a sajtó - a szabad sajtó - múködésének bemutatása sem hiányozhatott. A sajtószabadság biztosítása Szemere Bertalan szerint a mindenkori kormányzatnak is érdekében áll, hiszen amíg a sajtó ellen fellépő kormányra bukás, addig a sajtó mellett kiálló kormányra siker vár.

Bölöni Farkas Sándor franciaországi útinaplói a korlátozott királyi hatalmat, a kétkamarás törvényhozás felépítését, valamint a felelős miniszteri intézményt mutatták be. Az 1830-as júliusi forradalom után ugyanis Franciaországban megszűnt az abszolút monarchia, az ország uralkodója, Lajos Fülöp, az állam „első tis ‘tviselöje” lett, ugyanúgy viselkedik, mint az állam többi polgára: az utcán gyalog jár és meg is lehet szólítani.28

Az Egyesült Holland Királyságtól elszakadó és függetlenné váló Belgium az 1831-ben létrejövő alkotmányos monarchia intézményei miatt vált érdekessé Magyarországon, különösen az 1848-as polgári forradalom időszakában. ${ }^{29}$ A reformkori utazók, ha nem is kifejezetten célországként, de Belgiumot is útba ejtették. Bölöni Farkas Sándor találóan jellemezte a belgákat. „Amit Páriz̧s csinál, ažt csinálja Brüsszel, s Brüssz̧el után csinálják a többi belga városok. Brüsszel oly miniatúrája Párizsnak, s annyira mindenben követöje Párizsnak, hogy ami ott nagyban történik, az visszhangzile itt kicsiben, majd mindenben.” A belgák számára tehát a franciák mutatják a kibontakozás irányát; 1830. őszén Párizs mintája nyomán Brüsszel is megcsinálta „a maga revolúcióját.”’30 Az 1840-es évek folyamán Belgiumba elvetődő magyar utazók közül Tóth Lốrinc viszont részletesen számolt be a belga alkotmány alapelveiről, valamint a törvényhozás szervezetéről és múködéséről. A „követkamra” ülésén tett látogatás igen kedvező benyomásokat keltett az útirajz szerzőjében: „, $A^{\prime}$ viták elég élénken folytak, a' francziáknak saját fürgeségével's tisz̨ta, pontos és szabatos beszédével." 31

A kontinentális Európa partvidékeit elhagyva Anglia kapcsán Szemere Bertalan elsősorban a fogházakat ajánlotta olvasói figyelmébe. A hazai büntetőpolitikai reformok egyik szorgalmazójaként Angliát megjárt kortársaihoz, Bölöni Farkas Sándorhoz, Gorove Istvánhoz és Tóth Lórinchez hasonlóan, kellő részletességgel mutatta be a büntetés-végrehajtás reformjára irányuló börtönrendszerek, a hallgató-rendszer és a magány-rendszer múködését ${ }^{32}$, miközben a hazai börtönviszonyok tarthatatlanságára is felhívta a figyelmet.

Az útleírások szerzői többnyire kedvezően vélekedtek Angliáról. „Európának e’ pillanatban legérdekesebb pontja Angolhon. Oda néz minden politikai felekezęt' vezére, mint mágnestöre a' kormányos..." írta Pulszky Ferenc. ${ }^{33}$ Gorove Istvánnak kifejezetten az volt a véleménye, hogy a nagyszerűség érzete kíséri keresztül az utazót Angolhonban. ${ }^{34}$ A demokrata érzelmű Irinyi József viszont egyáltalán nem volt elragadtatva Angliától, mert bár a kereskedés és a múipar - azaz a kézmúipar és a gyáripar -

\footnotetext{
${ }^{27}$ Az esküdtszék intézményének bemutatása mások útirajzaiban, így pl. Tóth Lőrinc 1844-ben közzétett úti tárcáiban is hangsúlyos szerepet kapott.

${ }^{28}$ BÖLÖNI, Napnyugati utazás 177. 1831. március 16-i bejegyzés.

${ }^{29}$ Az 1831-es belga alkotmány rendelkezéseit és magyarországi hatását lásd ERDŐDY, A független belga alkotmányos monarchikus rendszer 7-10.

30 BÖLÖNI, Napnyugati utazás 180-181. 1831. március 30-i bejegyzés.

31 Tóth, Úti tárcza 107.

32 SZEMERE, Utazás külföldön 280 ff. 1837. június 19-i bejegyzés.

33 PULSZKY, Úti vázlatok 46.

${ }^{34}$ GOROVE István: Nyugot. Utazás külföldön. Második kötet. Pest, Heckenast Gusztáv, 1844. 117.
} 
terén az angolok bámulatos eredményeket értek el, Angliát az érdemi reformoktól ódzkodó konzervatív arisztokrácia hazájának tartotta. ${ }^{35}$ De még az Anglia iránt megmutatkozó általános rokonszenv sem volt elegendő ahhoz, hogy ne ítéljék el az angolok írországi politikáját. Az útirajzok szerzői mély ugyanis együttérzéssel írtak az Írországban tapasztalt nyomorról. Az írek fôvárosát,

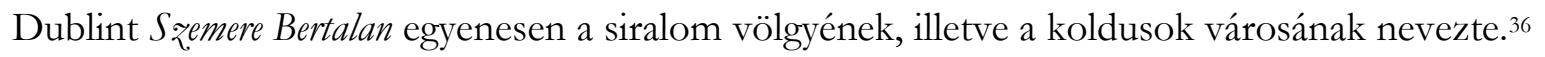

3. Az ifjú Szücs Miklós a naplóbejegyzések tanúsága szerint többször is elolvasta Bölöni Farkas Sándor észak-amerikai útinaplóját. ${ }^{37}$ Az útinapló szerzője annak idején abból a célból szelte át az Atlanti Óceánt, hogy a magyarok közül elsőként tudósítson szándékai szerint átfogó jelleggel az Amerikai Egyesült Államok alkotmányos életéről, politikai és társadalmi berendezkedéséről: „Gondolkozám, mi lehet utazásomban, mely mégis sokak figyelmét magára vonta? mert azok oly mindennapi ideák. Amerikában és Angliában, s oly sokaktól elprédikáltattak már, hogy szinte a közönséges ember is tudja, s elóttem is most éppen mindennapiak. Úgy látom, kevés magyarnak volt módja vagy kedve Amerikára fordítani figyelmét s az erróli munkákot olvasni, s mivel én a sokaktól mondottakot egybesummáżtam magyarul, ez teszi az érdeket. Meglehet, sokak csalódását elrontanám, s authorságom becse is alább szállna, de mégis szerenetném valamely íásban megvallani a publicum elött, hogy az egész. munkát csak a szeemrehányástól való félelmem szülte. Míg nem utaztam volt, mindig şitkozódtam azok ellen, kik utaznak s mégsem irják le utazásukat, s sok másoktól is ęt hallom. Mármost belébozám magam e kelepcébe, s gondolám, minden ember méltán fogja szemedbe lobbantani, hogy te is a szóvitézele közé tartozol! - és irám, amit irtam, bizony nagy részént a számadás félelme miatt." - írta naplójába már a nyugat-európai és az észak-amerikai utazásról hazaérkezvén. ${ }^{38}$

Bölöni Farkas Sándor lelkes híve volt az USA-nak. „Hatvan esz̨tendeje már annak, hogy Európának és az emberiségnek sz̨emei Amerikára vannak függesztve." ${ }^{39} \mathrm{Az}$ alapító atyák történelmi érdemeként emelte ki, hogy nem ismertek el semmiféle ,státusvallást’, hogy nincs állandó katonaság, hogy eltörölték az örökös hivatalokat, hogy nincs ,titkos polícia”, de a legfontosabbnak azt tartotta, hogy a törvényhozó, végrehajtó és ítélő - azaz bírói - hatalmat egymástól teljesen elválasztották. ${ }^{40} \mathrm{Az}$ útinapló szerzője elismeréssel írt a fogvatartottakkal szemben humánus bánásmódra törekvő amerikai börtönrendszerekről, a magányos elzáráson alapuló pennsylvaniai, illetve az örökös munkára alapozott auburni rendszerről is: „Miután Franciaországban és Angliában nehány fogházat láttam, s a bazánkbeliekre is visszaemlékeztem, az amerikaiak annyi magasztalására hittem ugyan, bogy itt csinosabb épületekben sjobb rendben tartott rossz. embereket látok - de az̧t nem is képzeltem, hogy a megjobbitásra, az. elmének és léleknek ily machinériáit lehessen feltalálni; nem véltem, hogy ezen erkölcsi machinák a megátalkodott gazemberre is ily behatással lehessenek." 41

Az amerikai demokrácia és szabadság iránti lelkesedését a rabszolgaság intézményével történt szembesülés lohasztotta le. Marylandi utazása idején olvasott ugyanis egy hirdetményt, amely a „szerecsen” rabszolgák árverését adta tudtul. „Mintha jégkéz vonult volna el szivemen ennek

\footnotetext{
${ }^{35}$ IRINYI, Német-francia- és angolországi úti jegyzetek 178.

36 SZEMERE, Utazás külföldön 355. 1837. augusztus 5-i bejegyzés.

37 „Bölöni Farkas Sándor észak amerikai utazását Pomázról magammal hozuán elolvastam, most másod ižben.” SzŰCS, Napló 112. 1841. június 7-i bejegyzés.

38 BÖLÖNI, Napnyugati utazás 557-558. 1836. február 18-i bejegyzés.

${ }^{39}$ BÖLÖNI, Napnyugati utazás 304.

40 BÖLÖNI, Napnyugati utazás 315. és 489.

${ }^{41}$ BÖLÖNI, Napnyugati utazás 362 ff.
} 
olvasására! s tehát rabszolgák országába érkętünk." - fakadt ki elkeseredésében. ${ }^{42}$ Bölöni Farkas Sándor amerikai útja idején az USA 24 tagállama közül 13 törölte el teljesen a rabszolgaság intézményét.

4. Trefort Ágost a következőképp vonta meg az 1836. évi nyugat-európai utazás mérlegét a visszaemlékezései lapjain: „Eq az utazás rendkivüli módon jó hatással volt rám, elösegitette érésemet, és évekekel öregbitett. Mint ifjonc mentem el, s mint férfi jöttem meg. Gyakorlati érzékeem kifejlödött, s nemcsak látóköröm tágult, de külsö megjelenésem is finomodott, és megtanultam megérteni a világot és az, embereket." ${ }^{43} \mathrm{Az}$ útleírások ugyanakkor a látókör tágítása révén a magyarországi reformok számára is szolgálhattak az alkotmányos eszmék és alkotmányos intézmények transzfere révén első kézből származó információkkal, illetve a közügyek iránt érdeklődő olvasóközönséget akár meg is győzhették a bevezetendő reformok szükségességéről. A realitásokkal azonban, legfőképp a szuverenitás hiányából fakadó politikai mozgástér szűkösségével, szembe kellett nézni.

Talán erre is utalhattak Erdélyi János 1845-ös franciaországi úti levelének kissé szkeptikus gondolatai: „Újabb idókben sok magyar utazik - velem együtt - a mivelt külföldön, sjobbára sikerül venni tölïk valamit az irodalomban, honunk felvirágzására szolgálót. Az ipar és keresködés meglelék szószólóikat; a boldogitási tervek nyomban érik egymást, és hála érte, van látjatok elóbb-utóbb. (...) Óhajtanám az angol keresködését, intézeteit, de abhoz egy szigetke szü̈kéges, meg egy óceán; vágynám a francia politikát, de abhoz. harmincmillió lélekbü̈l álló nemzetke szüleséges, egy világréssz̧el, mely fôvárosomra figyeljen; de az efféle vágyódásban elpárolog jobb erönk, s kivibetlenre vész lángolásunk." 44 A reformkori útleírások, útilevelek és útinaplók a földrajzi és szellemi horizont tágításával mindazonáltal nagy szolgálatot tettek, amint erre Széchenyi István sorai is rámutatnak, aki hálás köszönetét fejezte Bölöni Farkas Sándornak az észak-amerikai úti élmények közzétételéért, hiszen a könyv „haszna honosinkra nézve felsqámithatatlan.”45 Hasonló érzés keríthette hatalmába a külföld megismerése iránt olthatatlan vágyat érző ifjú Szücs Miklóst is Bölöni Farkas Sándor és Szemere Bertalan úti beszámolóinak elolvasása után.

\section{Felhasznált források és irodalom}

ifj. BARTHA Lajos: Nagy Károly, egy reformkori tudós az Újvilágban. In: Földrajzi múzeumi tan. 8. Érd 1990 BÖLÖNI Farkas Sándor: Napnyugati utazás. Napló. Válogatta, szerekesztette és a tanulmányt írta: MALLER Sándor. Budapest 1984

ERDÉLYI János: Úti levelek, naplók. Válogatta, szerkesztette és a bevezető tanulmányt írta: T. ERDÉLYI Ilona. Budapest 1985

ERDŐDY Gábor: A független belga alkotmányos monarchikus rendszer megteremtése. Jogtörténeti Szemle 2010/1. 7-10.

FENYŐ István: A polgárosodás eszmevilága útirajzainkban 1848 előtt. Irodalomtörténeti Közlemények 1964/5-6. 603612.

HALÁsz Iván: Wenzel Gusztáv és a magyar jogi komparatisztika kezdetei. Pro Publico Bono, 2015/3. 152-162.

\footnotetext{
42 BÖLÖNI, Napnyugati utazás $467 \mathrm{ff}$.

43 TREFORT, Önéletleírás 12.

${ }^{44}$ ERDÉLYI, Úti levelek 348-350.

45 Széchenyi István levele Bölöni Farkas Sándornak (Orsova, 1834. szeptember 10.), idézi: JAKAB, Bölöni Farkas Sándor és kora 297.
} 
IRINYI József: Német-francia- és angolországi úti jegyzetek. Sajtó alá rendezte és az utószót írta: FENYŐ István. Budapest 1998

JAKAB Elek: Bölöni Farkas Sándor és kora. Keresztény Magvető, 1870/4.

KAJTÁR István: A 19. századi modern magyar állam- és jogrendszer alapjai. Európa - haladás - Magyarország. Budapest - Pécs 2003

KECSKEMÉTi Károly: Magyar liberalizmus 1790 - 1848. Budapest 2008

NAGY Károly: Utazási töredékek Éjszak-Amerikából. Társalkodó 1832. december 29.

PULSZKY Ferenc: Úti vázlatok 1836-ból. In: Pulszky Ferenc kisebb dolgozatai. Sajtó alá rendezte: LÁBÁN Antal. Bevezetéssel ellátta: MARCZALI Henrik. Budapest 1914 (Erdetei kiadás: Budapesti Árvízkönyv I. köt. Budapest 1839) SzEMERE Bertalan: Utazás külföldön. Válogatás Szemere Bertalan nyugat-európai útinaplójából. Válogatta és szerkesztette: STEINERT Ágota. A tanulmányt írta: SŐTÉR István. Budapest 1983

SzALAY László: Eredetiség 's utánzás a’ politica’ mezején. Pesti Hírlap, 1844. július 17. In: SzALAY László: Publicistai dolgoztok. Első kötet 1839-1844. Pest 1847 (Reprint kiadás: Budapest 1988)

SZÉCHENYI István - WESSELÉNYI Miklós: Feleselő naplók. Válogatta, szerkesztette és a tanulmányt írta: MALLER Sándor. Budapest 1986

SZALAY László: Úti naplómból 1838-1839. V. Athenaeum, 1839. szeptember 22.

SzỨcs Miklós naplója 1839-1849. Sajtó alá rendezte és a tanulmányt írta: KILIÁN István. Miskolc 1981

TóTH Lőrincz: Úti tárcza. Első füzet. Déli Németföldön. Pest 1844

TREFORT Ágoston önéletleírása. Fordította: BARSI János. Sátoraljaújhely 1991

WeSSELÉNYI Polixéna: Olaszhoni és schweizi utazás http://mek.oszk.hu/01000/01017/01017.htm

ZÁvodsZKY Géza: Az Amerika-motívum és a polgárosodó Magyarország. A kezdetektől 1848-ig. Budapest 1992 